DOI: https://doi.org/10.34069/AI/2021.46.10.4

How to Cite:

Fu, X., Cherevko, K., \& Pysmenna, O. (2021). Performing Skills of Li Yundi in the context of China's leading trends in the piano art development. Amazonia Investiga, 10(46), 42-50. https://doi.org/10.34069/AI/2021.46.10.4

\title{
Performing skills of Li Yundi in the context of China's leading trends in the piano art development
}

\section{Виконавська майстерність Лі Юнді в контексті провідних тенденцій розвитку фортепіанного мистецтва Китаю}

Received: July 26, 2021
Accepted: September 12, 2021

Written by:

Fu Xi ${ }^{10}$

https://orcid.org/0000-0002-9468-9827

Cherevko Kateryna ${ }^{11}$

https://orcid.org/0000-0001-5877-4429

Pysmenna Oksana ${ }^{12}$

https://orcid.org/0000-0003-0899-8613

\begin{abstract}
The article examines how the performing skills of the outstanding Chinese pianist Li Yundi have been formed. Chinese piano art in a short time has reached the significant success. As Chinese performers have made a rapid rise in their skills, we can speak about the formation of special musical-performing principles, based on a strong national basis. Li Yundi's career success owed not only to a successful teaching methodology, but also to a deliberate state policy. The formation of Chinese piano pedagogy lies in the assimilation of European pianist-teachers' experience and the preservation of ancient Chinese national traditions. Chinese pedagogues-pianists often use elements of ancient art 'Qigong'. The use of teaching methods in the two performing styles of "Wen" and "Wu" traditionally established in Chinese culture is also important.

This work is intended to identify the leading developmental trends in Chinese piano performing and their role in the formation of young Chinese pianist Li Yundi's performing skills. The article reveals the peculiarities of Chinese piano performing, with its integration of European piano school performing traditions. Emphasis is placed on the performing problems of Chinese pianists' interpretation of European composers' piano works. Li Yundi, one of the finest performers of Frideric Chopin's works, is a notable example of Chinese piano pedagogy's
\end{abstract}

\begin{abstract}
Анотація
Стаття присвячена розгляду шляхів формування виконавської майстерності видатного китайського піаніста Лі Юньді. Китайське фортепіанне мистецтво за короткий термін досягло значних успіхів. Стрімке зростання майстерності китайських виконавців, дає змогу говорити про формування особливих музичновиконавських принципів, в основі яких яскраво виявляється міцне національне підгрунтя. Успіх кар“єри Лі Юньді завдячує не лише успішній методології навчання, а й цілеспрямованій політиці держави. Формування засад китайської фортепіанної педагогіки пов'язане із засвоєнням досвіду європейських піаністів-педагогів та збереженні давніх китайських національних традицій. Китайські педагоги-піаністи часто використовують елементи давнього мистецтва «Цігун». Важливим $\epsilon$ i застосування методів навчання у двох виконавських стилях «Вен» і «Ву», які традиційно склалися у китайській культурі. Мета роботи полягає у визначенні провідних тенденцій розвитку китайського фортепіанного виконавства та їх ролі у формуванні виконавської майстерності молодого китайського піаніста Лі Юньді. У статті розкриваються особливості китайського фортепіанного виконавства, яке інтегрує у собі виконавські традиції
\end{abstract}

\footnotetext{
${ }^{10}$ Post-graduate student of Lviv National Music Academy named after Mykola Lysenko, Lviv, Ukraine.

${ }^{11} \mathrm{PhD}$ in Art criticism, Associate Professor, Lviv National Music Academy named after Mykola Lysenko, Lviv, Ukraine.

12 Ph.D in Art criticism, Professor, Head of The Theory of Music Department, Lviv National Music Academy named after Mykola Lysenko, Lviv, Ukraine.
} 


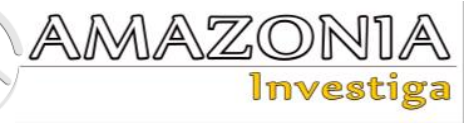

successes in the multifaceted development of the pianist's personality.

Keywords: Chinese piano performing, Chinese pianist, Li Yundi, piano pedagogy.

\section{Introduction}

The piano performance in China has become a unique phenomenon that developed rapidly at the turn of the XX - XXI centuries and caused a true "piano mania". Probably it is difficult to imagine any serious piano competition without the participation of Chinese pianists. In less than a century, China has created all the conditions for the successful development of piano performing and pedagogy, and piano education has become a mass phenomenon since the 80's of the twentieth century.

The most impressive are the successes of Chinese pianists at renowned international piano competitions, because despite the lack of long history of the Chinese piano pedagogy, their performances show a high level of performing skill. This is especially true of performing technique, which often comes to the fore. One of the world's leading trends today is the development of virtuoso performers, whose technical ability is almost the main criterion in the judging of competitions

The current successes of Chinese piano pedagogy are embodied in the emergence of a number of outstanding pianists who are active in concert performing. Among them, Lang Lang, Li Yundi, Wang Yuqia, Zhang Haocheng, Zhang Shenliang, Chen Sa and others. They are all young Chinese pianists who received their musical education in China and, after participating in leading piano competitions, perfected their skills in the classes of outstanding European pianists.

The aim of the work is to identify the leading trends in the development of Chinese piano performing and their role in shaping the performing skills of the young Chinese pianist Li Yundi. європейської фортепіанної школи. Окрема увага приділяється виконавським проблемам інтерпретації фортепіанних творів європейських композиторів китайськими піаністами. Виконавська майстерність Лі Юньді, одного з найкращих виконавців творів Фрідеріка Шопена, є яскравим прикладом успіхів китайської фортепіанної педагогіки, спрямованої на різносторонній розвиток особистості виконавця-піаніста.

Ключові слова: китайське фортепіанне виконавство, китайський піаніст, Лі Юнді, фортепіанна педагогіка.

\section{Theoretical Framework or Literature Review}

An analytical review of literature, which reveals the problems of Chinese piano art is based on several categories of works. The issues of specificity of formation and history of development of piano art in China are revealed in the works of Bian Meng (1994), Wang Changkui (2010a), Bo Tu (2019), Liu Xiaolong (2009) and others. A significant number of scientific works is devoted to the formation of the principles of Chinese piano pedagogy. They are works by Wang Changkui (2010b), Niu Iatsian (2019), Wang Saowei (2010), Liu Yanchen (2016), Jia Jifeng (2021), etc.

An important place in the study of the performing characteristics of Chinese pianists is occupied by works on the theory and history of the development of piano performing: Aizenshtadt S.A. (2014), Bian Meng (1994), Jia Jifeng (2021), Xue Bo (2011), Taraeva G. (2011) and others. The principles of performing skills of the Chinese Pianist Li Yundi are highlighted in a small number of publications, internet sources and interviews: Dyakov E. (2016), Fedorov I. (2010), Li Yin \& Yi Yunwen (2007), Liao R. (2016), etc.

\section{Methodology}

The methodological basis of the study consists of a complex of scientific methods: Source Studies is used to study scientific works on Chinese piano performing and Chinese piano pedagogy; Historical - for examination the development stages of piano performing in China; Biographical - to reproduce Li Yundi's creative path; Musicological - to consider the specifics of Chinese pianist's performing skills. 


\section{Results and Discussion}

Piano performing and its rapid development in China is a topic to which modern researchers are addressed. The Chinese piano pedagogy in a relatively short period of time has succeeded in raising a whole generation of pianists who amaze the world with their high level of professionalism.Researchers call this situation the "piano mania" emphasizing the fact that without a national piano school, China has achieved enormous scale in the spreading and interest of the instrument in society. This situation researchers are called a "piano mania", emphasizing that without a national paper for piano, China has reached a huge scale in spreading and popularity of the instrument in society.

Chinese piano music culture is the combination product of Chinese and Western culture, which has not only revealed the unique flavor of Chinese piano music, but also manifested unique charm of Chinese music culture. It is extension and development of traditional music culture to some extent. From perspective of various concrete aspects, it is brilliant achievement by absorbing ancient and foreign essence (Deng \& Yu, 2015 p. 1693).

Obviously, the reasons for the "piano mania" in China have to do with historical as well as political and ideological conditions.

One such reason is the honorable position of music in the Chinese spiritual tradition of the people, for it was music that constituted an important role in human upbringing and development. Confucius gave music the leading place among the four educational requirements (playing chess, drawing, writing hieroglyphics). It was in Confucius' time that the first schools of music were established and the profession of musician appeared. However, a musician, in addition to being able to play an instrument, must be able to listen. Therefore, such deep mental traditions are a guarantee of a huge interest of Chinese to learn music.

In Confucianism there was no place for innovations and updating. Therefore, Chinese culture was in isolation during the millennia, because the policy of the state, its political concept of "closed doors" was based on Confucianist principles.The teaching of Confucius was the basis of Chinese politics until the begining of the twentieth century.
After the protests of Chinese intelligentsia and students in 1919, which were associated with the ideas of Europeanization of Chinese society, the studying of European culture was started. The piano, as a symbol of European culture, played an important role in the introduction to European culture. In the last decades of the twentieth century, the piano became a symbol of new musical education, a sign of Europeanization and Cultural globalization.

Considering that the state policy during the period of the People's Republic of China was to actively develop Chinese piano music, this was the determining criterion for the "piano mania" at the turn of the twentieth and twenty-first centuries. The policy of "openness", actively pursued by the Chinese government in the early 1980s, was aimed not only at assimilating European cultural traditions, but also at increasing Chinese people's level of education. Therefore, China opens musical and educational institutions including conservatories and musical departments in pedagogical institutes.

As Xue Bo (2011, p. 63) notes, the works of the French pianist Richard Clayderman, who performed classical repertoire in modern arrangements, contributed to the process of the popularity of the piano. "Critics call him "the greatest promoter of the piano since L. Beethoven" and he is, without exaggeration, known to practically all Chinese. Millions of people attend his concerts and his recordings are sold in incredible numbers in China".

In addition, the bright pianist-performer's career is an undeniable fact that also encourages piano lessons. They are inspired by a number of pianists' careers, whose commercial support is astounding. So, pianist's commercial "promotion" by various public organizations has become a peculiar experiment of our millennium. Lang Lang's career is an example of the successful way a Chinese pianist has created, shattering the traditional system of authorities in the piano performing arts. As the researcher Xue Bo says, "Thanks to this powerful classical artist's commercialisation, the whole world was to look afresh at pianists from countries with no traditions or piano schools" (Xue Bo, 2011, p. 63-64).

The pianist's brilliant career is a model to follow, as Chinese youth are thrilled by the prospect of solo touring, performing with renowned conductors and orchestras, and working with famous recording companies. Such a Chinese pianist's career path causes concern about the fact 


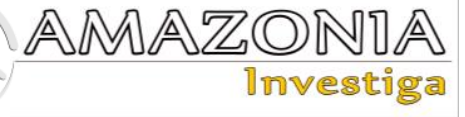

that contemporary piano performing art is becoming purely commercial. So, we can quote the famous pianist, Professor Eliso Virsaladze (2010, March 28):

Today our art is going through difficult times, and it will probably get worse. Just think of it we are facing an army of twenty-five million Chinese professional pianists, all dreaming of a Lang Lang's career. Her rather critical thought underlines again the fact that Chinese pianists are rapidly gaining pedestals of superiority in the world of piano art.

\section{National sources of performance style of Chinese pianists}

In the young Chinese pianists' works we can observe the formation of new musical and performing principles linked to national cultural traits, their world outlook and philosophy of life. Chinese pianists-teachers often use elements of the ancient Chinese art "Qigong" or "Chi gung", based on control vital energy Qi.

The Qigong system is based on breathing exercises, which play an important role in the musical performing process. Philosophy and practical exercises of this system are actively used in forming pianists' skills and improving their level of performing capabilities.

Qigong is an important element within Chinese Medicine and the foundation of martial arts practices such as T'ai Chi. The primary aim of qigong is to gently build and regulate vitality by enhancing Qi. If practised regularly qigong can lead to improved physical health, mental clarity and emotional well-being (Pianodao, n.d.).

Generally speaking, piano pedagogy is known to be based on the coordination of body movements and breathing while performing pieces of music.Well-known pianist Andras Schiff said in an interview with Pianist Magazine:

For me, it is breathing that is vital. You must breathe naturally, like a singer. Pianists and string players often tend to forget the necessity of breathing and they can become very tense; then they get back pains and wrist pains and so on. Usually it can be sorted out through the breathing (Pianodao, n.d.).

We can identify three types of exercises for pianists corresponding to the understanding and practical values of the qigong philosophy.The first group includes exercises aimed at physical development of the performer.These exercises are performed without piano. These exercises are not done behind an instrument, they do relaxation, develop flexibility and balance and bring awareness to every movement of the body.The next group includes breathing exercises that allow controling breath. The last group consists of meditation exercises, which help to focus and calm the mind, relieve stress and anxiety.

Chinese piano education has its own specifics. In general, the methods of musical pedagogy are based on two different performing styles: Wen 文 (Calm and Quiet) and a wu 武 (Athletic and Dynamic). The training of the performer in these two styles is the main task of the Chinese teachermusician. The performance style Wen, based on specific performance traits, is associated with emotional or non-emotional performance, so it requires the performer to show not open emotions, but the reproduction of deep emotional experiences. It encompasses broader interpretative tasks, and aims at revealing the composer's style and the richness of the imagery of the musical works. Wen's performaning style echoes the basic principles of Confucianism, according to which "open behavior" is dangerous to society and negatively affects people's health. Human emotions should not be manifested through physical body movements. Thus, the ancient Chinese educator Fu Lei said: "When the body is calm, the spiritual life reaches its perfection - it is an invariable principle" (Fu, 1984, p. 58).

Opposite to the style Wen is the style of Chinese piano performing $W u$, which means "militant". With this style of musical performing, the performer proceeds to demonstrate feelings and emotions openly. According to Chinese educators, such performing can violate the principle of the "golden mean". However, despite the Chinese cultural specificities, it is Wu style that has become the pianists' leading performing style in the early twenty-first century.Obviously, the fact of studying European pianists' video recordings, with much brighter levels of emotional performing and onstage demeanor, is a factor. Following the performing traditions, developed in the European piano school, Chinese pianists today resort to the so-called "open" performing style.

Thus, Bian Meng (1994, p.20) notes, Chinese pianists' performing style is based on "Reproduction of famous interpretations or change of listening reference points, skillful imitation or coincidence of features, graceful copying or creative originality...". Contemporary 
research increasingly indicates that contemporary Chinese pianists' piano playing style is a unique phenomenon that is not always unequivocally appreciated by European audiences.

One of the most important factors in Chinese pianists' performing is to recreate the depth of the figurative and emotional content of works. Thus, Chinese performers must not only have a more varied skill set, but also an emotional understanding of European composers' works of piano.Therefore, in the works of young Chinese pianists we can observe the formation of new musical and performing principles.

Niu Iatsian (2019) notes:

The Integration of both national components in a single methodological model became possible thanks to three factors: the only educational goal pursued by Russian and Chinese teachers, namely, moral and spiritual education; the only semantic basis of national principles and methods; the implementation of pedagogical guidelines adopted in one culture through the principles and methods of the other culture (p.112).

Despite the similarity of the basic methodological principles and their integration occurs mutual reading of each national music and pedagogical system. The integration of the pedagogical foundations of piano performing results from the globalization of education, through which one gets to know another people's culture and realizes of the interrelation of different national cultures. A famous pianist Bao Huiqiao once remarked that,

"If performers do not perform their own national works, foreign performers cannot be counted on to do as well. I am able to apprehend these works only because I am Chinese. Although these works are still in a stage of development, you must understand them and elaborate them by using the Chinese aesthetic point of view." Therefore, it's necessary to first develop one's own music culture, so as to better integrate foreign music into it and promote the common development of music of all countries and nationalities (Bo, 2019).

Chinese piano playing has two components: first, it is musicality, expressiveness, and emotionality, and second, it is extremely virtuosic. Chinese pianists are often accused of overemphasizing performing technique over interpretation of the figurative world of a work, resulting in "changes in the modern world of cultural and psychological attitudes to the perception of the interpretation of a musical work." (Bian, 1994, p. 20).

The idea of changing the perception of a musical work is also noted in G.Taraeva's works, who points out the leading trend of modern performing art, in which there is a shift of emphasis from the depth of disclosure of the figurative world of a musical work towards technically perfect performing (p. 21).

The commercial organization of performing in the genres of the academic tradition and creating "stars" of the classical repertoire along the lines of "pop culture" formed an audience with new tastes, criteria, and appreciation. Composers' names, individual works transformed by professional management into "brands," an advertised "product" for consumption " (Xue Bo, 2011, p. 22).

Therefore, piano performing moves away from the understanding of the concept of the work, the individuality and originality of its interpretation.All this is replaced by the performer's extreme technical equipment and demonstration of their capabilities. Chinese pianists' emotionally "flat" presentation of a piece of music is often identified by European researchers as a performing deficiency. Therefore, Chinese teachers actively work on expressiveness of musical intonation with their students.For this, they turn to an analysis of European pianists' performances, essentially imitating their emotional manner of performance. Chinese performers are actively studying the works of European composers of different genres and styles. This contributes to the formation of hearing skills that is a guarantee of successful performing of musical works. The initial process of imitation of performer's the behavior on stage is a leading factor in emotional education of the Pianist. Therefore, the process of studying European pianists' behavior on the stage on video records is for Chinese pianists one of the main ways to achieve the success of their performing career in Europe.

\section{Ways of forming Li Yundi's performing skills}

Yundi Li (Li Yundi) - famous Chinese pianist, who in October 2000 became the winner at the XIV International Chopin Piano Competition in Warsaw. He became the youngest winner of this famous competition, because at that time he was only 18 years old. His masterful performing of Chopin's polonaise impressed the jury so much 


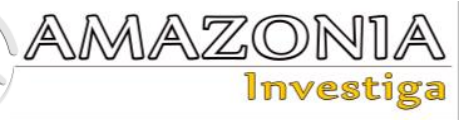

that the Polish F. Chopin Society awarded him a special prize.

Li Yundi was born on October 7, 1982 in Chongqing, central China, Sichuan Province to a non-musical family. The beginning of the pianist's musical education is associated with a fairly early age, and it began with learning to play the accordion. His first success was winning the Children's Accordion Competition in his hometown of Chongqing. At the age of seven, he began learning the piano with Dan Zhaoyi (Zhao-Yi), who was one of the most famous Chinese pianists at the time. Li Yundi was taught by Dan Zhaoyi for nine years, and it was under his guidance that he won first prize at the Chopin Competition in Warsaw.Yundi decided on his career as a professional pianist at the age of nine, and since then he has worked hard to master all the basics of piano technique.

In 1994, the boy auditioned for the Sichuan Provincial Music School, the same year he won the Children's Piano Competition in Beijing. His further studies are connected with the transfer of his teacher Dan Zhaoyi to the Shenzhen School of Arts. His family decides to move to Shenzhen to continue their son's education. However, they could not pay for tuition, so the school awarded LiYundi a scholarship and paid his expenses for trips abroad to competitions, from which he almost always returned the winner. Thus, the Shenzhen School of Arts has made a huge contribution to the development of Li Yundi's talent.

One of the first Yundi's important victories was the first place in the International Youth Piano Competition named Stravinsky in the US in 1995. He has been active in competitions all over the world. In 1998 he took the third place in the junior group at the Missouri Southern State University International Piano Competition, and in 1999 he won the third prize at the F. Liszt International Piano Competition in Utrecht (Netherlands) and the first prize at the International Piano Competition in Beijing. At the Gina Bachauer International Piano Competition, he took the first place in the category of young performers. The peak of his career was his victory at the International Chopin Competition in Warsaw. After that, Li Yundi no longer took part in any competition trials, devoting himself wholly to performing.

Yundi Li continued improving his performing art in Germany under the guidance of renowned piano teacher Arie Vardi at Hanover High School of Music and Theater (Hochschule fuer Musik und Theater). However, after studying he returned to Hong Kong, where he lives to this day.

Despite his rather active concert activities, Yundi is still engaged in self-improvement, so he spends part of his time studying new works. He believes that the public needs only overt emotion, so it is important for good performing. Besides playing concerts, Li Yundi actively makes recordings. For a long time he was Deutsche Grammophon's (DG) exclusive artist. Not surprisingly, the pianist's first studio disc, recorded in 2002, was a solo album of music by F. Chopin.This debut album by Li Yundi sold 100,000 copies in Japan, Korea and China.

Yundi $\mathrm{Li}$ is active in concert performing and tours extensively abroad (in Europe, America and Asia). His performing career is focused not only on solo concerts, he also performs extensively as a soloist with renowned orchestras and conductors.

\section{Yundi Li in an interview said:}

I'm really honored and pleased to be an ambassador for cultural exchange, especially for classical music. I love to hear that many Chinese people, especially the young generation, begin to love classical music after coming to my concerts. Also, I always play some Chinese pieces as an encore when I perform abroad. In this way, I want to show the audience around the world some Chinese music. I've felt greater responsibility as time goes on, as more children in China are playing the piano now (Liao, 2016, December 19).

Li Yundi's concert career was highlighted by his performance at the Chopin Jubilee Festival in Warsaw, dedicated to the bicentennial of the composer's birth. Besides, the pianist has made a number of concert tours in Europe and America. His performing at the Chopin Jubilee celebrations in Warsaw brought a storm of delighted critical acclaim.

The teacher Dan Zhaoyi o played an outstanding role in shaping Li Yundi's performing skills. His pedagogical principles were aimed not only at developing perfect performing technique, but also at forming the right approaches for interpreting European composers' works. Despite the difference in mentality, Li Yundi's performing is not just a perfect technique. The soul and poetic-romanticism of the figurative world of a piece of music is evident in his performing. A separate page in the pianist's 
mastery of music is his interpretations of Chopin's works. No wonder Li Yundi is called the "Chinese Chopin", one of the best performers of Chopin's works.

Li Yundi's performing skills were formed thanks to China's successful education system and effective teaching methods, aimed not only at developing a perfect performing technique but also a deep understanding of the content of musical works and the interpretation of their imagery. The pianist's work thus confirms once again the universality of art, as his perfect performing of Chopin's works was rewarded with victory at the International Frédéric Chopin Competition in Poland. Dan Zhaoyi was Li's only teacher in China and from childhood he developed in his pupil the best qualities of a pianist, with full technique, intonation and emotional intensity.

Li is so concentrated, and gifted with a spiritual affinity with music. His playing gives voice to the profound meanings inherent in the composition. The most striking aspect of Yundi Li's performance is his sensibility combined with a romantic vein, the qualities that Chopin equally possesses..." says professor Dan Zhaoyi (China.org.cn, n.d.).

Li Yundi's performing is always accompanied by strong emotional content, drama and depth of content and imagery, combined with perfect phrasing and detailed elaboration of each musical.The pianist's strong feelings create a vivid interpretation of the classics, which always has a fresh and new sound. His excellence lies above all in the openness of feeling, each musical phrase sounding balanced, which is achieved with great attention to detail in work. Clearly, Li's secret to excellence lies in his perfect technique, combined with an extreme musicality and a subtle and poetic perception of the music.

The calmness of Yundi Li's playing comes from the extraordinary mobility and flexibility of his fingers and hands. The result is a type of piano playing that is exciting precisely because it is so natural. The mysteries and depths lie in the music itself. And these appear even more powerful when played in so wonderfully light and sensitive a way (China.org.cn, n.d.).

\section{Yundi Li's victory at the International Chopin Piano Competition}

The International Chopin Piano Competition has a long history. This competition remains one of the most prestigious for modern pianists. The first competition took place in 1927 in the concert hall of Warsaw Firm Monuments. The idea was to pass on the tradition of piano playing Chopin's works and to bring out the best interpreters of the composer's works.Each contestant's performance is seriously judged by a jury, so no first prize was awarded during 1990 and 1995.

The history of the Chopin Competition contains Chinese pianists' names participating in different years. So, in 1955, the third prize received a Chinese participant Fou T'song. Chinese pianists Ming-Qiang Li, Yifan Liu, Shiqun Liu, Lang Lang, and $\mathrm{Sa}$ Chen participated in the competitions. However, only Li Yundi won.

In October 2000, Yundi Li became a member of the XIV International Chopin Piano Competition. Before the competition trials, the pianist said he hoped to hear musicians perform at a high level. However, he noted that the contest is a competition, so one should focus on expressing one's understanding of music "...his performance of Chopin's "Piano Concerto No. 1" made him the first participant to be awarded First Prize in 15 years and the youngest winner -- and the first Chinese citizen to do so -- in the competition's history” (Xinhua, 2015).

Li Yundi famously said to his teacher before the start of the second round: "I'm so excited I can't remember the notes, my head is a total fog" (Russian.china.org.cn, 2008, January 8). Considering how exhausting the competition was, Dan Zhaoyi forbade him to rehearse before the last stage of the competition. Instead, he took him for a walk in Chopin Park. Standing in front of the great composer's monument, Li Yundi said: "I feel like I'm getting closer to the great Chopin composer-virtuoso" (Russian.china.org.cn, 2008, January 8). Pianist received the biggest applause in the third round of the competition. Almost all members of the jury congratulated him on his successful performance.

In the finale, Li Yundi played Chopin's First Piano Concerto. He played quite inspirationally, deeply feeling the composer's intention, thoughts, and feelings. With excitement, he even stood up and began to conduct the orchestra, creating a unified harmony of sound. Impressed by the performer's emotion and mastery, the orchestra merged with him in a single burst. The impeccable technique and perfect harmony of the performing were the culmination of the competition, and the hall was filled with applause.The Polish audience was fascinated by 


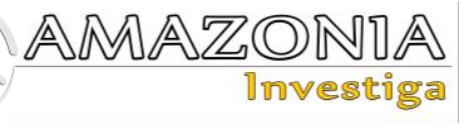

this thin young Chinese pianist's masterstroke (Russian.china.org.cn, 2008, January 8).

Li Yundi's performance impressed the jury so much that they awarded him the first prize. It is worth noting that no other contestant has won this award in 15 years. The pianist became the youngest winner of such a prestigious pianist award. Li Yundi remembers those minutes as follows:"During the performance, I forgot that it was a competition. I did my best and put in a lot of effort to express emotion. Being as calm as possible is enough" (Xinhua, 2015). In addition, Chinese pianists Li Yundi and Chen Sa, students of Dan Zhaoyi, received the Frederic Chopin Society Award for Best Polonaise Performance.

After the announcement of the results of the Competition, the chairman of the jury Andrzej Jasinski speaking about the winner of the first prize, told reporters:

Yundi Li is very mature for his age, and most importantly - he feels the music of Chopin. He is not contradictory in his interpretations, he plays with a beautiful sound and at the same time has imagination, charm and mother-of-pearl technology. This is even more important, because we did not hear too many outstanding interpretations of Chopin during this year's competition, as evidenced by the non-awarding of the prize for the best performance of the mazurka. (Educational platform of the Ministry of Education and Sciencev, n.d.).

Before Li Yundi, it is worth remembering that Chinese pianists, during Chopin's competition, did not receive such high awards. In 1955, for example, the pianist $\mathrm{Fu}$ Tsung won the third prize, while Li Mingjiang won the fourth in 1960. After that, Chinese pianists did not win prizes at the Chopin Competition for nearly 40 years.

Of course, after the competition journalists tried to unravel the success of $\mathrm{Li}$ Yundi's performance.

One of the Polish correspondents asked:

You played Chopin very well! How could you capture the "soul" of Chopin's music deeper than the Polish contestants? The pianist replied: "There are many people in both China and Poland. Some are able to understand Chopin, others are not. I am one of those Chinese who understand Chopin" (Educational platform of the Ministry of Education and Sciencev, n.d.).

The competition performance was recorded on CD, which contains Scherzo, Andante spianato and Piano Concerto. The pianist's victory in the competition has become an achievement in his performing career, as well as the achievement of all Chinese piano art. Li Yundi said: "Chopin's competition helped me climb the world scene. In addition, Chopin is my most beloved composer. Since I grew up on Chopin's music ..."(Dyakov, 2016).

\section{Conclusions}

The development of piano performing in China is closely related to musical pedagogy. The system of piano teaching forms a solid basis for the further development of pianists. In a short time, the Chinese piano education has achieved great success, its pupils actively perform and win prizes in outstanding pianist contests. The work of pianist Li Yundi today is a shining example of Chinese piano pedagogy's success. Tracing the formation of the performer's mastery, we turned to the peculiarities of the development of Chinese piano education, emphasizing its integrative nature. The integrative approach to teaching methodology, in turn, as a factor in the globalization of education, makes it possible to talk about a "dialogue of cultures," combining pedagogical methods established within the framework of different national cultures. Li Yundi's career is connected with his studies under the famous pianist-pedagogue Dan Zhaoyi, who was able to harmoniously develop in his pupil the necessary qualities of a performerinterpreter. Therefore, an important factor in Chinese piano pedagogy is the teacher's role in the educational process, the psychological and pedagogical aspects of teaching, and the specifics of approaches to the studying of musical works.

\section{Bibliographic references}

Aizenshtadt, S.A. (2014). On the Problem of Spiritual Leadership in Piano Schools of the Far Eastern Countries. Vesnik of Tomsk State University, 382, 75-80.

Bian, M. (1994). Essays of the formation and development of the Chinese piano culture. (Abstract of the thesis... Cand. Art history). St. Petersburg State Conservatory named after N.A. Rimsky-Korsakov. St. Petersburg.

Bo, T. (April, 2019). Study on the Development of Chinese Piano Music Culture. In Proceedings of the 3rd International Conference on Culture, Education and Economic Development of Modern Society: Advances in Social Science, Education and Humanities Research. https://doi.org/10.2991/iccese-19.2019.57 
China.org.cn (n.d.). Genius Pianist. Retrieved from http://www.china.org.cn/english/NMe/152350.htm

Deng, H., \& Yu, L. (April, 2015). Discussion on the Strategies of Nationalized Chinese Piano Education. In Proceedings of the 3rd International Conference on Management, Education, Information and Control. https://doi.org/10.2991/meici-15.2015.295

Dyakov, E. (2016, June 2.) Interviews of $\mathrm{Li}$ Yundi: "Chopin is my most favorite composer." Apelzin. Retrieved from https://www.apelzin.ru/special/li-yundi.html

Educational platform of the Ministry of Education and Sciencev (n.d.) The International Piano Competition. F. Chopin. Retrieved from https://epodreczniki.pl/a/miedzynarodowykonkurs-pianistyczny-im-f-chopina---okrespo-prl/Dt9di6Ns4

Fedorov, I. (2010, July 2) On the concert of Chinese Pianist Li Yundi. Belcanto. Retrieved from http://www.belcanto.ru/10070201.html.

Fu, M. (1984). Letters Fu Lei. Beijing.

Jifeng, J. (2021) The specifics of the influence of the Russion method of teaching piano on the professional training of pianists in China. Laplage in Review (International), Vol. 7, N. Extra D, p. 499-505. https://doi.org/10.24115/S2446622020217Extra-D1130p.499-505

Li, Y. \& Yi, Y. (2007). Chinese piano myth Li Yundi. Chinese Publisher: MIT Press King of Pop Jay.

Liao, R. (2016, December 19) A Chinese Master of Chopin. Supchina. Retrieved from https://supchina.com/2016/12/19/CHINESEMASTER-CHOPIN/

Liu, X. (2009). Sixty Years of Chinese Piano Art Development. Shanghai: Shanghai Conservatory of Music Press. 726 p.

Niu, I. (2019). About piano pedagogy in modern China. Teacher, XXI (2-1), 108-112.

Pianodao. (n.d.) Qigong and Piano Playing. Retrieved from https://pianodao.com/pianoqigong/what-is-piano-qigong/
Russian.china.org.cn. (2008, January 8). Young Chinese pianist Li Yundi. Retrieved from http://russian.china.org.cn/people/txt/200801/08/content_9496110.htm

Taraeva, G. (2011) Performer in modern culture: Changing the paradigm of perception. Musician executor in the space of world culture. Education, creativity, career management. p. 18-36. Retrieved from https://cyberleninka.ru/article/n/kitayskiepianisty-na-rubezhe-hh-hhi-vekovispolnitelskie-dostizheniya-i-sistemaobucheniya/viewer

Virsaladze, E. (2010, March 28). Interview with Marina Arshinova. Forumklassika. Retrieved from http://www.forumklassika.ru/content.php?r= 204-virsaladze_interview $1 \&$ page $=7$

Wang, C. (2010a). Chinese piano culture. Beijing: Guan Minzhibao.

Wang, C. (2010b). Professional Piano Education in Chinese Piano Music Culture. International education studies, 3(1). Retrieved from https://pdfs.semanticscholar.org/cb75/5d1cc d704c4c4b9e5eb242fe8406d83dd3ce.pdf

Wang, S. (2010). A Study of Chinese Piano Education Since 1949. Hebei: Hebei Ped. Institute.

Xinhua. (2015, October 8). 'Chinese Chopin' Li Yundi advices young musicians. Chinadaily. Retrieved from https://www.chinadaily.com.cn/culture/2015 -10/08/content_22130692.htm

Xue, B. (2011). Chinese pianists at the turn of the XX-XXI centuries: performing achievements and training system. South Russian musical Almanac, (1), 59-68.

Yanchen, L. (2016). Peculiarities of Initial Piano Pedagogy in Contemporary China. In Proceedings of the International Conference on Arts, Design and Contemporary Education. https://doi.org/10.2991/icadce16.2016.324 